\title{
Female description of the hydrothermal vent cephalopod Vulcanoctopus hydrothermalis
}

\author{
A.F. González ${ }^{1, *}$, A. Guerra ${ }^{1}$, S. Pascual ${ }^{1}$ and M. Segonzac ${ }^{2}$ \\ ${ }^{1}$ ECOBIOMAR, Instituto de Investigaciones Marinas (CSIC), Eduardo Cabello 6, 36208 Vigo, Spain \\ ${ }^{2}$ IFREMER, Centre de Brest, Laboratoire Environnement Profond, BP 70, 29280-Plouzané, France \\ *: Corresponding author : González A. F., email address : afg@iim.csic.es
}

\begin{abstract}
:
During biological sampling of hydrothermal vents on the East Pacific Rise, the manned submersible 'Nautile' caught the first female of the endemic cephalopod Vulcanoctopus hydrothermalis. The specimen caught at the vent site Gromit $\left(21^{\circ} 3366^{\prime} \mathrm{S}, 114^{\circ} 1798^{\prime} \mathrm{W}\right.$ at $2832 \mathrm{~m}$ depth) is described here in detail and an amended diagnosis of the species proposed. The external morphology, measurements and internal structure resemble that of males of this species. One of the most remarkable characters is the lack of spermathecae and the absence of apical filaments in the oocytes to provide a site for sperm storage. It is suggested that some species of the genera Benthoctopus and Bathypolypus would be the most suitable octopod ancestor of $\mathrm{V}$. hydrothermalis.
\end{abstract}

Keywords: hydrothermal vent; cephalopods; Vulcanoctopus hydrothermalis; female description 


\section{INTRODUCTION}

The study of chemosynthetic ecosystems in the deep sea represents a challenging issue due to the difficulty of sampling, which involves the use of modern technologies such

72 as manned submersibles. Vent animals were useful as flux indicators of hydrothermal activity for geologists prospecting for vents, who appreciated the need for an explanation of the large biomass of animals and of the means by which species could be maintained at vents in the face of local extinctions (Desbruyères et al., 2006). Since the first studies accounted back in the 1970s, many charismatic vent organisms have been discovered in these chemosynthetic environments. Thus, dozens of new species of clams, mussels, limpets, crabs or cephalopods, among others, have been identified and later classified, constituting a remarkable source of information regarding these extreme environments.

Based on the samples obtained in one of these studies, a new Octopoda genus and species Vulcanoctopus hydrothermalis González \& Guerra, 1998 was erected. This classification was made based on two male specimens. These individuals were caught during the French cruise HOT 96, two meters from the main black smoker of Genesis site, which is located at $12^{\circ} 48.43^{\prime} \mathrm{N}-103^{\circ} 56.41^{\prime} \mathrm{W}$, at $2600 \mathrm{~m}$ depth on the East Pacific Rise (González et al., 1998). The possibility of raising a new sub-family (Vulcanoctopodinae) within the Octopodidae was then discussed for the first time. The parasites found in these two individuals allowed us to erect also a new genus and species of copepod, Genesis vulcanoctopusi López et al., 2000.

In these hydrothermal vents, only benthic incirrate octopuses of Graneledone and Benthoctopus and benthopelagic cirrate octopus species of Cirrotheuthis and Grimpoteuthis have been reported, and only $V$. hydrothermalis have been recognised as endemic of these sites (Desbruyères et al., 2006). This benthic species has characters that represent either adaptations to the deep-sea (absence of ink sac, loss of the anal flaps, eye without iris and optic chiasma) or to a hydrothermal vent habitat (eyes are covered by a thin semi-translucent skin, high concentrations of metals and presence of amoebocytes clots in the venous system and in the renal sacs). It inhabits an isolated extreme environment among colonies of tube worms Riftia pachyptila and Alvinellidae polychaetes, or mussels Bathymodiolus thermophilus, very close to the base of the chimneys where hot water gushes out of the vents in the sea bed at temperatures $265^{\circ} \mathrm{C}$ forming a dense plume of black "smoke" made up of minute particles of metal sulphides (Campbell et al., 1988), and also observed on the pillow lava at several meters from the active areas (González et al., 1998). 
102 From a total of 30'18' of sequences involving twenty-five specimens of $V$. hydrotermalis filmed between 2600 and $2650 \mathrm{~m}$ depth in the East Pacific Rise (EPR) during

104 the French cruise HOPE 99, the following behaviour patterns were described for the first time in this species: a) crawling, b) take off, c) tactile feeding, d) mounting and e) distance

106 mating (Rocha et al., 2002). Afterwards, the capture of seventeen new males of $V$. hydrotermalis during HOPE 99 allowed us to describe the main morphological variations of

108 this species. This information completed and improved the knowledge of the species (González et al., 2002). The analysis of the stomach contents showed that $V$. hydrothermalis

110 preys mainly on Crustacea Decapoda (probably galatheid crabs) and bathypelagic species like Halice hesmonectes (Rocha et al., 2002; Voight, 2005)

112 An intriguing aspect of the samples used in these papers was the absence of females, which suggested the existence of a spatial segregation by sex (González et al., 2002).

114 The objective of the French cruise BIOSPEEDO (Biologie-Sud Pacifique Est-Etude de la Dorsale Océanique) using the submersible Nautile, onboard the R/V L'Atalante, was the

116 study of the biodiversity and geodiversity of the hydrothermal vents along the east Pacific Rise between $7^{\circ} 24^{\prime} \mathrm{S}$ and $21^{\circ} 33^{\prime} \mathrm{S}$. During this cruise, the first female specimen of $V$.

118 hydrothermalis was collected at the hydrothermal vent site Gromit in April 2004 (Jollivet et al., 2004).

120 The aim of this paper is to describe, for the first time, the female of Vulcanoctopus hydrothermalis, which allow completing its diagnosis and description.

\section{MATERIAL AND METHODS}

A female Vulcanoctopus hydrothermalis of $34.9 \mathrm{~mm}$ mantle length (ML) was caught during the dive PL 1578 (Figure 1), by the robotized arm grab of the manned submersible

126 Nautile, on the site Gromit, (EPR, $21^{\circ} 3366^{\prime} \mathrm{S}, 114^{\circ} 1798^{\prime} \mathrm{W}$ ) at $2832 \mathrm{~m}$ depth in April 2004 (Jollivet et al., 2004).

128 The specimen was collected near by a high temperature hydrothermal vent, on a mussel bed of Bathymodiolus thermophilus and Calyptogena magnifica, crawling among

130 stalked barnacles (Neolepas cf. rapanui), bythograeid crabs Bythograea spp., several fish species (Causse et al., 2005), and chiridotid holothurian Chiridota sp. The animal was caught

132 in very good condition. It was fixed in formaldehyde (4\% in sea water) and preserved in $70 \%$ ethanol. 
134 Definition of counts, measurements and indices follow Roper \& Voss (1983) and Clarke (1986).

136 The female was dissected and the digestive tract, reproductive tract, circulatory and excretory systems, and eyes were removed for detailed description. The reproductive

138 apparatus was sectioned for analysing the maturity stage, number and size of oocytes and also to perform histological sections stained with haematoxylin and eosin. All oocytes in the

140 ovary were measured, counted and photographed using the Image Analysis System Eclipsenet $^{\circledR}$. The specimen is deposited at the ECOBIOMAR cephalopod collection with the 142 reference number VH06030.

RESULTS

\section{Female external and internal description}

146 The external morphology of the female is very similar to that of male (Figure 2). There were not, however, parasitic cysts in the skin as found in several males of EPR-13 ${ }^{\circ} \mathrm{N}$ (López

148 et al., 2000). Measurement, counts and indices after preservation are summarized in Table 1.

The mantle cavity and the digestive tract of female have similar characteristics to those of

150 males (González et al., 1998). However, the dark swelling observed and described for males was not present in the female specimen. The digestive tract of female contained some food

152 remains, which were impossible to identify. The circulatory, excretory and nervous systems are also similar to those of males.

154 The reproductive tract of the female comprises a pear shaped ovary and two oviducts (Figure 3). No external seminal receptacles were found. The posterior edge of the ovary fits 156 into posterior part of the mantle. The proximal part of the oviducts is short (POLI = 17.2) and narrow in this specimen, which is in a maturing stage, with spermatophores attached to the

158 external part of the ovary. The oviducal glands are almost spherical and of uniform white colour, its maximum diameter measuring $1.6 \mathrm{~mm}(\mathrm{OGDI}=4.6 \%)$. The distal part of the 160 oviducts is relatively long (DOLI $=46.7 \%)$.

The histological structure of the oviducal glands is composed of an outer endothelial 162 layer and an underlying connective tissue sheet, which appears profusely innervated and vascularized. In the inner part are the proximal and distal glands, both multilobulated and 164 rounded by smooth muscular tissue covered by connective tissue and outer endothelium. The above glands are also innervated and vascularized, and they contain the lumen of the oviduct which is about $0.4-0.5 \mathrm{~mm}$ diameter. This lumen is surrounded by a thick wall composed of a 
smooth muscular coat formed by two layers of fibres lying in a particular orientation (the 168 outer circular and the inner longitudinal). The wall of the lumen is covered by an endothelilal layer, which at regular intervals form expansions of this tissue. Therefore, each oviducal

170 gland is structurally divided into two concentric glands around the oviduct and separated by muscular and connective tissue. Seminal receptacles (spermathecae) were absent (Figure 4).

172 The ovary wall is very slender and translucent. It was adhered to the internal side of the mantle. The ovary wall is $65 \mu \mathrm{m}$ thick (mean) and it is formed of three layers: the outer squamoush endothelial tissue, an intermediate lax connective tissue and the inner squamoush cell layer of endothelial tissue.

176 Eighty finger-like oocytes of different sizes, ranging from 0.15 to $4.0 \mathrm{~mm}$ maximum length and between 0.5 and $0.6 \mathrm{~mm}$ of maximum width, were counted in the ovary. Figure 5

178 shows the oocytes size distribution. The oocytes lack of peduncles and were fixed by their bases to the inner side of the ovary wall (Figure 6).

Body semi-translucent, with a muscular consistency; mantle pear-shaped and 182 posteriorly mitre-like; presence of a large white body (which covers the eye, the optic nerves and the optic lobe), a crop, and a multilobulate digestive gland; absence of an ink sac. Arms

184 1.5-4.3 times ML. Two rows of suckers on each arm. Arm formula typically 1.2.4.3 or 1.2.3.4. No enlarged suckers. Maximum depth of the largest sector of the web about $22 \%$ of 186 the longest arm. Gills with 7-8 lamellae per demibranch. Right arm III hectocotylized (HA 1.5-2.1 times ML) in males. Ligula short (8-10\% of HA), lance-shaped and without 188 transverse ridges. Calamus represents 30 to $50 \%$ of the ligula length in fully mature specimens. Spermatophore length $70-125 \%$ of ML. Finger-like oocytes (80) ranging from

$190 \quad 0.15$ to $4 \mathrm{~mm}$ maximum length lacks of peduncles. Oviducal glands without spermathecae.

\section{DISCUSSION}

One of the most remarkable character of $V$. hydrothermalis female is the lack of 194 spermathecae. The absence of these reservoirs in the oviducal glands has been previously reported in four Eledone species (E. cirrhosa, E. moschata, E. massyae and E. gaucha), 196 which suggest that this is a consistent characteristic of this uniserial arm sucker genus (Pérez et al., 1990). On the other hand, the inner structure of the oviducal glands of $V$. 198 hydrothermalis is identical to that described in Pteroctopus tethracirrhus (Morales, 1973, Figs. 44 y 45), which indicated that this species also lacks of spermathecae. Therefore, this 
200 absence is not circumscribed to the subfamily Eledoninae, but also to some members of the Octopodinae such as P. tetracirrhus, and could be a not infrequent character among the 202 Octopoda.

As described by Mann et al., (1970) in Octopus dofleini, after copulation, a 204 'spermatophoric reaction' takes place in which the sperm rope within the spermatophore is everted, together with a toothed ejaculatory apparatus. This complex process proceeds inside 206 the mantle cavity of the female where are placed the sperm-free remnants of the spermatophores, dangling freely from the openings of the oviducts while the spermatangia 208 are found within the oviduct of the female (Boyle, 1983). Sea water stimulates the motility of the spermatozoa, and they enter the lumen of the oviducal gland where they remain attached

210 to the epithelium of the spermatheca (Froesch and Marthy, 1975). Spermatozoa are able to be viable there until the oocytes become mature. The duration of the sperm storage is variable,

212 from several weeks in E. cirrhosa from the Mediterranean (Mangold et al., 1971), to ten months in Bathypolypus arcticus (O'Dor and Malacaster, 1983). Fecundation of the oocytes

214 occurs in the lumina of the oviducal gland just before spawning. However, this is not the case of the four eledonid species neither of $V$. hydrothermalis, which lack of spermatechae. In the

216 eledonid octopuses, the spermatophores penetrate in the oviducts and oviducal glands reaching the ovarian cavity, in which the spermatophoric reaction takes place. Spermatangia

218 in form of bladders are found in the ovary of E. cirrhosa and E. moschata mated females and consequently fertilization is completely internal (Boyle, 1983; Mangold, 1983). However, in

220 E. massyae and E. gaucha the apical filaments of the oocytes provide a site for sperm storage and fertilization mechanism. Modified follicular cells surrounding the sperm mass inside the

222 filament are supposed to keep spermatozoa viable until oocytes are ripe (Pérez et al., 1990). The oocytes of $V$. hydrothermalis lack of apical filaments and not spermatangia in form of

224 bladders were observed inside the ovary. Therefore, the fertilization mechanism remains unknown in this species.

226 Whatever is the fertilization mechanism, the existence of an Octopodinae such as $P$. tetracirrhus (a benthic deep sea octopod inhabiting waters of about $800 \mathrm{~m}$ depth) lacking 228 spermathecae and with two rows of suckers in the arms, point out the possibility of the colonisation of extreme environments, such as hydrothermal vents, by a group of octopods 230 with biserial suckers on the arms. Phylogenetic relationships of $V$. hydrothermalis are still unknown. However, considering structural, biogeographical and ecological reasons, some 232 species of the genera Benthoctopus and Bathypolypus would be the most suitable octopod 
ancestor of $V$. hydrothermalis. Perhaps Benthoctopus, which lacks of an ink sac, would be the best candidate. Nevertheless, molecular analyses are necessary to test this hypothesis.

\section{ACKNOWLEDGEMENTS}

238 We thank Didier Jollivet (Chief scientist, Roscoff, France) and the team of the N/O L'Atalante and the submersible Nautile, for collecting the specimen studied here. We thank 240 also Violaine Martin and Patrick Briand (IFREMER, Brest) for the Fig. 1 and the Fig. 2, respectively. The cruise was supported by the French programme DORSALE and the ECCHIS-GDR (CNRS \& IFREMER).

\section{REFERENCES}

Boyle, P.R., 1983. Eledone cirrhosa. In. Boyle P.R. (ed.). Cephalopod Life Cycles. Vol I. Species account: 365-386. Academic Press, London.

Campbell, A.C., Palmer M.R., Klinkhammer G.P., Bowers T.S., Edmond J.M., Lawrence J.R., Casey J.F., Thompson G., Humphris S., Rona P. \& Karson J. 1988. Chemistry of hot springs on the Mid-Atlantic Ridge. Nature, 335, 514-519.

Causse R, Biscoito M, Briand P., 2005. First record of the deep-sea ell Ilyophis saldanhai (Synaphobranchidae, Anguilliformes) from the Pacific Ocean. Cybium, 29, 413-416.

Clarke, M.R., 1986. A Handbook for the identification of cephalopod beaks. Clarendon Press. Oxford, 273 pp.

Froesch, D. \& Marthy, H.J., 1975. The structure and function of the oviducal gland in octopods (Cephalopoda). Proceedings of the Royal Society Series B, 188, 95-101.

González, A.F., Guerra A., Pascual S, Briand P., 1998. Vulcanoctopus hydrotermalis gen. et sp. nov. (Mollusca, Cephalopoda): an octopod from a deep-sea hydrothermal vent site. Cahiers de Biologie Marine, 39, 169-184.

González, A.F., Guerra, A., Rocha, F. \& Briand, P., 2002. Morphological variation in males of Vulcanoctopus hydrothermalis (Cephalopoda). Bulletin of Marine Science, 71, 289298.

Desbruyères, D., Segonzac, M. \& Bright, M., (eds). 2006. Handbook of deep-sea hydrothermal vent fauna. Denisia, 18, $544 \mathrm{pp}$.

Jollivet, D., Lallier, F.H., Barnay, A.-S. et al., 2004. A new survey of hydrothermal vents along the South East Pacific Rise from $7^{\circ} 24^{\prime}$ S to $21^{\circ} 33^{\prime}$ 'S. InterRidge News, 13: 20-26.

López-González, P.J., Bresciani, J., Huys, R., González, A.F., Guerra A. \& Pascual, S., 2000. Description of Genesis vulcanoctopodi gen. et sp. nov. (Copepoda: Tisbidae) parasitic on a hydrotermal vent octopod and a reinterpretation of the life cycle of cholidynid harpacticoids. Cahiers de Biologie Marine, 41, 241-253.

Mangold, K., 1983. Eledone moschata. In: Boyle P.R. (ed.). Cephalopod Life Cycles. Vol I. Species account. Academic Press, London: 387-400.

Mangold, K., Boletzky S.v. \& Froesch. D., 1971. Reproductive biology and embryonic development of Eledone cirrhosa (Cephalopoda: Octopoda). Marine Biology, 8, 109117.

Mann, T., Martin, A.W. \& Thiersch. J.B., 1970. Male reproductive tract, spermatophores and spermatophoric reaction in the giant octopus of the North Pacific, Octopus dofleini martini. Proceedings of the Royal Society, Ser. B, 175, 31-61.

Morales, E., 1973. Contribución al estudio de la morfología, estructura y anatomía microscópica de la región visceral de Pteroctopus tetracirrhus D. Ch. (Octopoda, Incirrata). Investigación Pesquera, 37, 353-518. 
282 O’Dor, R.K \& Malacaster, E.G., 1983. Bathypolypus arcticus. In: Boyle P.R. (ed.). Cephalopod Life Cycles. Vol I. Species account: 401-410. Academic Press, London.

284 Pérez, J.A.A., Haimovici, M. \& Cousin, J.C.B., 1990. Sperm storage mechanisms and fertilization in females of two South American eledonids (Cephalopoda: Octopoda).

286 Malacologia, 2, 147-154.

Rocha, F., González, A.F., Segonzac M. \& Guerra. A., 2002. Behavioural observations of the 288 cephalopod Vulcanoctopus hydrothermalis. Cahiers de Biologie Marine, 43, 299-302.

Roper, C.F.E. \& Voss, G.L., 1983. Guidelines for taxonomic descriptions of cephalopods 290 species. Memoires Natural Museum Victoria, 44, 49-63.

292 bathypelagic amphipods of Halice hesmonectes. Journal of the Marine Biological Association of the United Kingdom, 85, 985-968. 
Table 1. Measurements (mm), counts and indices of Vulcanoctopus hydrothermalis female after preservation. DOLI (Distal Oviduct Length Index or length of the distal part of the oviduct as a percentage of ML), POLI (Proximal Oviduct Length Index or length of the proximal part of the oviduct as a percentage of ML) and OGDI

298 (Oviducal Gland Diameter Index or diameter of the oviducal gland as a percentage of ML). (AF) Arm Formula: Comparative length of arms expressed numerically in decreasing order of arms numbered from dorsal to

300 ventral; (ALI) Arm Length Index: oral surface from the lips to the tip of the arm as a percentage of mantle length; (ASC) Arm Suckers Counts: number of suckers per row on each arm; (CaLI) Calamus Length Index:

302 length of the calamus measured from the last (distal most) sucker to its distal tip as a percentage of ligula length; (EDI) Eye Diameter Index: diameter of eye across bulbus as a percentage of ML; (FFuI) Free Funnel

304 Index: the length of the funnel from the anterior funnel opening to the point of dorsal attachment to the head as a percentage of ML; (FuLI) Funnel Length Index: from the insertion point into the mantle to the tip as a

306 percentage of ML; (GiLI) Gill Length Index: from the proximal filament to tip as a percentage of ML; (HWI) Head Width Index: across widest point between the eyes as a percentage of ML; (LCL) Lower Crest Length:

308 length from the rostrum to the top of the two lateral walls of the lower beak; (LHL) Lower Hood Length: length from the tip of the rostrum to the posterior end of the hood of the lower beak; (LRL) Lower Rostral Length:

310 length from the rostrum to the shoulder of the lower beak; (LiLI) Ligula Length Index: from distal most sucker to tip of arm as a percentage of hectocotylized arm; (ML) Mantle Length: posterior of body to point midway

312 between the eyes; (MWI) Mantle Width Index: across widest point as a percentage of ML; (MS) Maturity Stage: Immature or mature; (PAI) Pallial Aperture Index: the measurement between the points to the attachment

314 of the mantle to the head along the ventral margin of the mantle as a percentage of ML; (SDI) Sucker Diameter Index: the diameter measured across the aperture from outer rim to outer rim as a percentage of mantle length

316 (ML); (SpLI) Spermatophore Length Index: total length of the spermatopohore as a percentage of ML; (TL) Total Length: from end of longest arm to posterior end of mantle; (UCL) Upper Crest Length: length from the

318 rostrum to the top of the two lateral walls of the upper beak; (UHL) Upper Hood Length: length from the tip of the rostrum to the posterior end of the hood of the upper beak; (URL) Upper Rostral Length: length from the

320 rostrum to the shoulder of the upper beak; (WDI) Web Depth Index: measurement of deepest sector of web measured from mouth to midpoint of sector between arms as a percentage of ML. (Web sector A, dorsal to

322 dorsal arm; B, dorsal to dorso-lateral; C, dorso-lateral to ventro-lateral; D, ventro-lateral to ventral; E, ventral to ventral); (WF) Web Formula: Comparative depth of each web sector, alphabetically in decreasing order. (I)

324 Immature; (M) mature and (D) damaged.

\begin{tabular}{|c|c|c|c|c|c|}
\hline ML & & 37.9 & SDI & & 5.8 \\
\hline MS & & Maturing & DOLI & & 47.6 \\
\hline TL & & 165.5 & POLI & & 17.2 \\
\hline MWI & & 69.9 & OGDI & & 4.6 \\
\hline HWI & & 47.0 & WDI & $\mathrm{A}$ & 21.8 \\
\hline EDI & & 19.2 & & $\mathrm{~B}$ & 19.1 \\
\hline \multirow[t]{8}{*}{ ALI } & L1 & 376.5 & & $\mathrm{C}$ & 17.4 \\
\hline & L2 & 310.6 & & $\mathrm{D}$ & 15.4 \\
\hline & L3 & 291.4 & & $\mathrm{E}$ & 13.9 \\
\hline & L4 & 261.3 & WF & $\mathrm{A}>\mathrm{B}>\mathrm{C}>\mathrm{D}>\mathrm{E}$ & \\
\hline & $\mathrm{R} 1$ & $\mathrm{D}$ & PAI & & 40.9 \\
\hline & $\mathrm{R} 2$ & 118 & GiLC & & 8 \\
\hline & R3 & 106 & GiLI & & 34.1 \\
\hline & $\mathrm{R} 4$ & 90 & FuLI & & 16.1 \\
\hline \multirow[t]{8}{*}{ ASC } & L1 & 126 & FFuL & & embedded in the skin \\
\hline & L2 & 118 & URL & & 0.67 \\
\hline & L3 & 100 & UCL & & 5.62 \\
\hline & L4 & 90 & UHL & & 2.02 \\
\hline & $\mathrm{R} 1$ & $\mathrm{D}$ & LRL & & 0.31 \\
\hline & $\mathrm{R} 2$ & 118 & LCL & & 4.25 \\
\hline & R3 & 106 & LHL & & 1.79 \\
\hline & $\mathrm{R} 4$ & 90 & & & \\
\hline
\end{tabular}


Figure 1. Map showing the locality where Vulcanoctopus hydrothermalis female has been 342 collected (solid circle).

344 Figure 2. Photograph of the unique female Vulcanoctopus hydrothermalis collected to date

346 Figure 3. The reproductive system of the $V$. hydrothermalis female. DO: distal oviduct; EI: external view by transparency of the egg insertion; O: ovary; OG: oviducal gland; PO: 348 proximal oviduct.

350 Figure 4. The histological structure of the oviducal glands of $V$. hydrothermalis showing the absence of spermatophores reservoir.

352

Figure 5. Size (maximum length in $\mathrm{mm}$ ) egg distribution within the ovary of $V$. 354 hydrothermalis.

356 Figure 6 . The oocytes of $V$. hydrothermalis lack of peduncles and are fixed by their bases to the inner side of the ovary wall. 
370

372

374

376

378

380

382

384

386

388

390

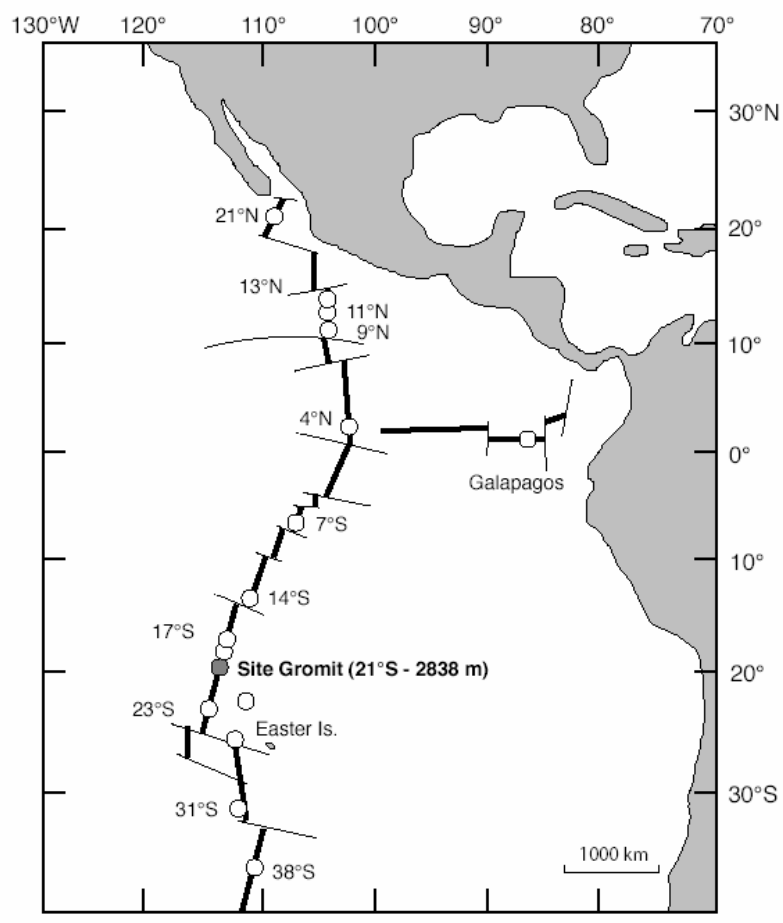

392

394

Figure 1. González et al.

396

398

400

402

404

406

408

410

412 
416

418

420

422

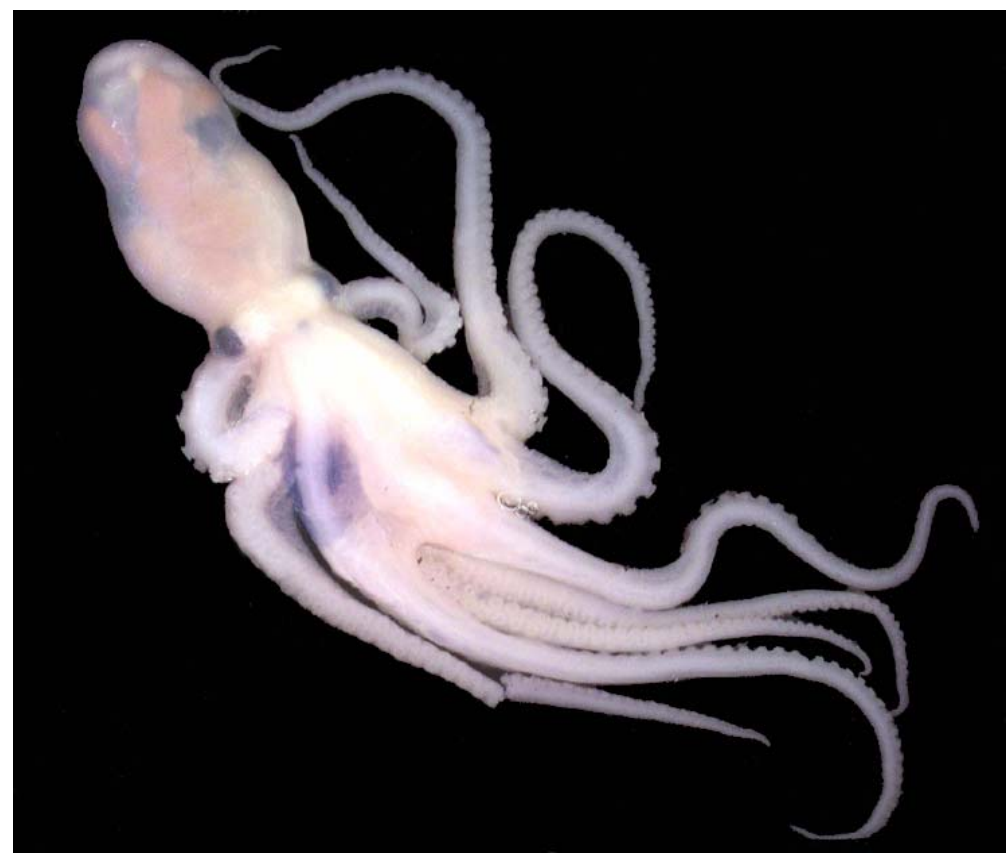

424

426

Figure 2. González et al.

428

430

432

434

436

438

440

442

444

446 
450

452

454

456

458

460

462

464

466

468

470

472

474

476

478

480

482

484

486

488

490

492

494

496

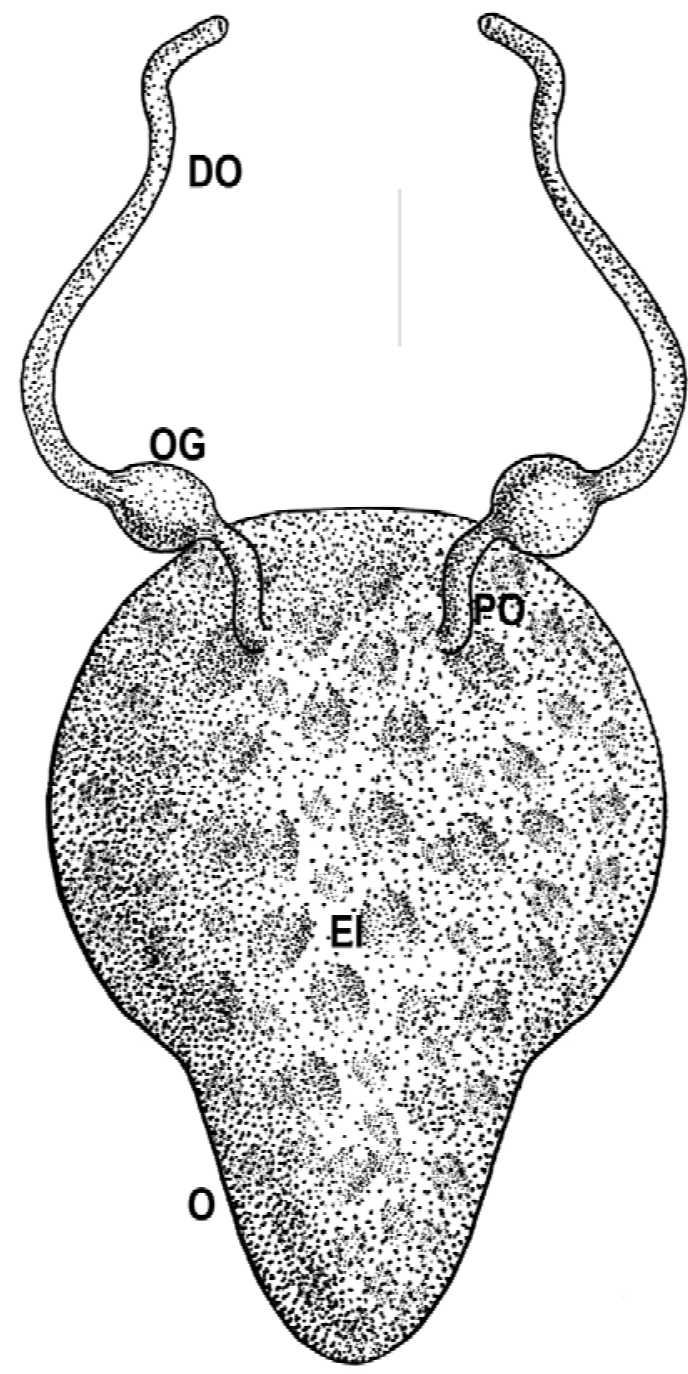

498

500

502

504 


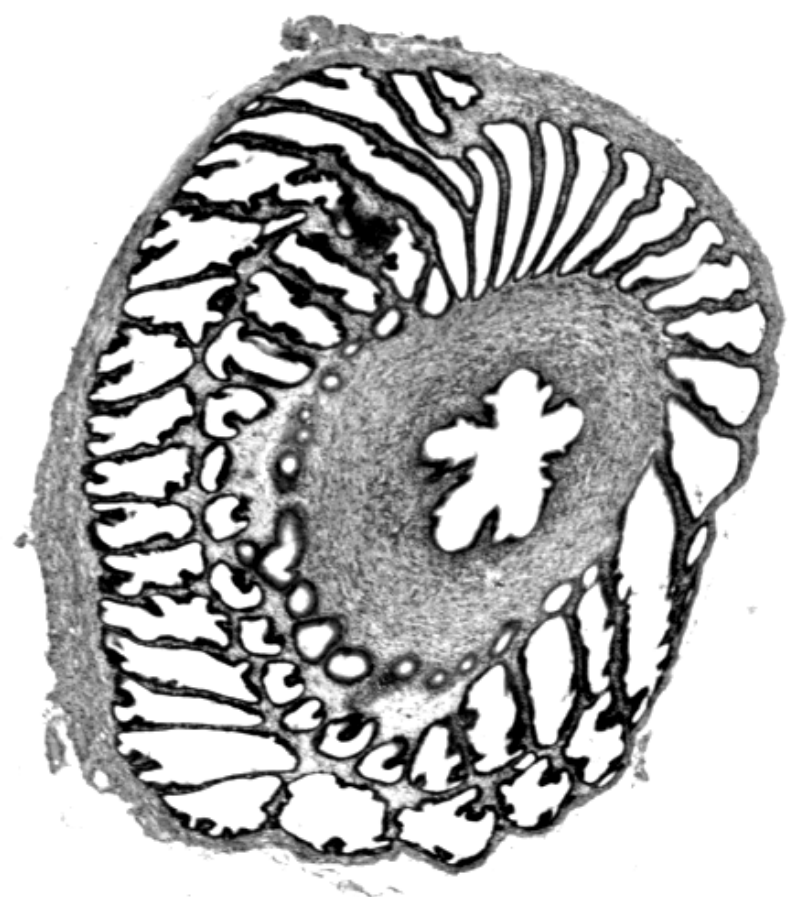

Figure 4. González et al.

514

516

518

520

522

524

526

528

530

532

534

536 
550

552

554

556

558

560

562

564

566

568

570

572

Figure 5. González et al.

574

576

578

580

582

584

586

588

590 
592

594

596

598

600

602

604

606

608

610

Figure 6. González et al.

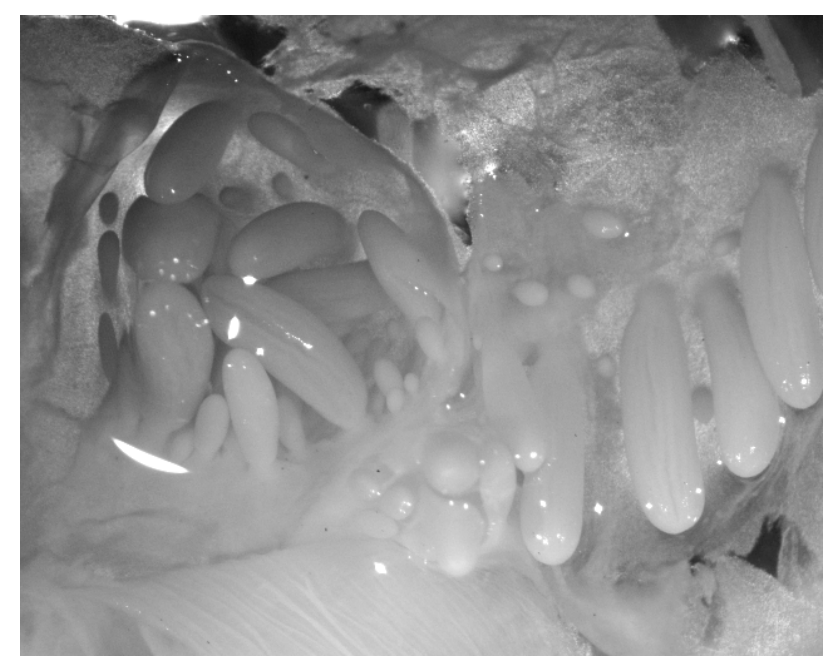

612

614

616

618 